Madrygal. Revista de Estudios Gallegos

ISSN: $1138-9664$

\title{
O apoio galego a Unamuno cando foi desterrado a Fuerteventura ${ }^{1}$
}

\author{
Raimundo García Paz
}

Recibido: 23 de outubro de 2019 / Aceptado: 15 de xullo de 2020

Resumo. O pensador español don Miguel de Unamuno "non camiñou só" cando foi desterrado pola Ditadura de Primo de Rivera desde Salamanca a Fuerteventura (Illas Canarias), en febreiro de 1924. Personaxes procedentes de Galicia, ao carón de figuras vinculadas á masonería, facilitaron a súa acolleita na illa do vento. O filósofo bilbaíno recorreu ao cirurxián lucense José Goyanes Capdevila para conectar coa poderosa familia Castañeyra, tamén orixinaria de Lugo, que lle serviría de anfitrioa durante o seu illamento forzoso. A presente investigación revela datos descoñecidos da súa accidentada viaxe ata o arquipélago e os catro meses de confinamento, que compartiu con Rodrigo Soriano, o político federalista radical, igualmente vasco.

Palabras chave: desterro; Miguel de Unamuno; familia Castañeyra; Fuerteventura; Emilio G. López; José Goyanes Capdevila; Juan Madinaveitia; Ángel Ossorio y Gallardo; Rodrigo Soriano.

\section{[es] El apoyo gallego a Unamuno cuando fue desterrado a Fuerteventura}

Resumen. El pensador español don Miguel de Unamuno "no caminó solo" cuando fue desterrado por la Dictadura de Primo de Rivera desde Salamanca a Fuerteventura (Islas Canarias), en febrero de 1924. Personajes gallegos, junto con figuras vinculadas a la masonería, facilitaron su acogida en la isla del viento. El filósofo bilbaíno recurrió al cirujano lucense José Goyanes Capdevila para conectar con la poderosa familia Castañeyra, también originaria de Lugo, que le serviría de anfitriona durante su aislamiento forzoso. La presente investigación revela datos desconocidos de su accidentado viaje hasta el archipiélago y los cuatro meses de confinamiento, que compartió con Rodrigo Soriano, el político federalista radical, igualmente vasco.

Palabras clave: destierro; Miguel de Unamuno; familia Castañeyra; Fuerteventura; Emilio G. López; José Goyanes Capdevila; Juan Madinaveitia; Ángel Ossorio y Gallardo; Rodrigo Soriano.

\section{[en] Galician Support for Miguel de Unamuno when He Was Banished to Fuerte- ventura}

Abstract. The spanish thinker Miguel de Unamuno "did not walk alone" when he was banished from Salamanca to Fuerteventura (Canary Islands) by the Dictatorship of Primo de Rivera in february 1924. Figures from Galicia together with characters associated with the massonery helped in his recepction in the island of the wind. The Bilbao-born philosopher turned to the surgeon José Goyanes Capdevila, native of Lugo, to connect with the powerful family Castañeyra, also from Lugo, who hosted him during his forced isolation. The present investigation reveals unknown data about his

\footnotetext{
Por razóns de espazo, a segunda parte deste traballo, centrada na figura do doutor José Goyanes Capdevila, será considerada para a súa publicación no próximo número ordinario da revista Madrygal. Arquivos e bibliotecas consultados: Casa Museo Miguel de Unamuno (CMU) (Salamanca), Archivo General de la Administración (Alcalá de Henares), Biblioteca Nacional de España (Madrid), Universidad Complutense de Madrid (Biblioteca da Facultade de Medicina, Biblioteca Histórica Marqués de Valdecilla), Archivo de la Real Academia Nacional de Medicina (Madrid), Biblioteca Ferroviaria-Museo del Ferrocarril (Madrid), Archivo de la Junta de Castilla y León (Valladolid), Biblioteca y Archivo del Cabildo Insular (Fuerteventura), Biblioteca y Archivo del Ayuntamiento de Puerto del Rosario (Fuerteventura); Universidade de Santiago de Compostela (Biblioteca da Facultade de Medicina), Biblioteca Valenciana (Fondo Laureano Robles Carcedo). Fontes orais: Barros, Miguel; Cabrera Travieso, María del Carmen; Cerdeña Armas, Francisco Javier; Chaguaceda Toledano, Ana; Dr. Die Goyanes, Alfredo; Estévez González, Yeray; Goyanes Muñoz, María José; Losada Sanmartín, María Luisa; Machado Lang Lenton, Jorge; Mateo Castañeyra, Lorenzo; Rodríguez Rodríguez, Elías; Von de Twer, Hannelore; Dr. Zulaika Aristi, Daniel.

2 Licenciado en Dereito e Ciencias da Información (Xornalismo) pola Universidade Complutense de Madrid. Correo-e: rgarciap2003@gmail.com.
} 
rugged journey to the archipelago and the four months of confinement he shared with Rodrigo Soriano, the radical federalist politician, equally from Basque country.

Keywords: Exile; Miguel de Unamuno; Castañeyra Family; Fuerteventura; Emilio G. López; José Goyanes Capdevila; Juan Madinaveitia; Ángel Ossorio y Gallardo; Rodrigo Soriano.

Sumario. 1. Introdución. 2. Confinamento. 2.1. Real Orde de desterro. 2.2. Ruta por Madrid, vetada. 2.3. Choque de trens. 2.4. Entre tres e cinco horas de demora. 2.5. Ausencia de Jiménez de Asúa e Marañón. 2.6. Sen diñeiro no peto. 2.7. Dúas versións. 2.8. Puerto Cabras. 2.9. Os Castañeyra: "dramatis personae". 2.10. A biblioteca de Unamuno e Durruti. 3. "Nunca camiñarás só". 3.1. Un encontro premeditado. 3.2. O bravo Rodrigo Soriano. 3.3. Victoria Castañeyra Schamann, un nexo clave. 3.4. A reprimenda de Goyanes. 3.5. Un conflito entre paisanos. 3.6. A discordancia biográfica. 3.7. Os "amigos de Madrid". 3.8. Ossorio y Gallardo. 3.9. Cita en Atocha. 3.10. Unha hospitalidade fraternal? 4. Conclusións. 5. Referencias bibliográficas.

Como citar: García Paz, R. (2020): “O apoio galego a Unamuno cando foi desterrado a Fuerteventura", en $\mathrm{Ma}$ drygal. Revista de Estudios Gallegos 23 Núm. Especial, pp. 217-234.

\section{Introdución}

Cerca dun século despois do ostracismo padecido por Don Miguel de Unamuno en Fuerteventura, aínda quedan lagoas pendentes sobre as vicisitudes da súa deportación, xunto con episodios pouco coñecidos dese proceso, que despertan a natural curiosidade. Algúns dos seus protagonistas principais foron galegos, de nacemento ou ascendencia, mostrando unha solidariedade activa co intelectual, cando loitaba frontalmente contra a ditadura de Primo de Rivera.

Na súa meirande parte, esta investigación trata sobre o doutor José Goyanes Capdevila, oriúndo de Monforte de Lemos (Lugo) pero exercente en Madrid, cuxa celebridade como cirurxián era incuestionable naquela época, dentro e fóra de España. O traballo refírese tamén ao profesor Emilio González López, historiador e político coruñés, estudante da Facultade de Dereito na Universidade Central e fundador da FUE (Federación Universitaria Escolar) por aquelas datas, quen participaría, xa como catedrático de Dereito Penal, na elaboración do Estatuto de Autonomía de Galicia durante a II República.
Por fin, a nosa pescuda achégase a outras dúas persoas nadas en Fuerteventura, cuxos antergos eran orixinarios de Mondoñedo (Lugo). Chamadas respectivamente José Castañeyra Carballo -director do primeiro diario con que contou a illa citada- e Ramón Castañeyra Schamann -fillo do anterior, comerciante e intelectual autodidacta, quen chegou a ser delegado insular do Goberno da Monarquía. Ambos exerceron como anfitrións de don Miguel, durante a súa estancia forzosa nun lugar, cuxos integrantes se denominan a si mesmos majoreros.

Remontémonos ao xoves 21 de febreiro de 1924, no que Unamuno abandonou Salamanca camiño de Canarias baixo vixilancia policial. $\mathrm{O}$ biógrafo Emilio Salcedo (seudónimo do xornalista Emilio Sánchez Arteaga) alértanos na súa Vida de don Miguel do seguinte:

los amigos temen por la seguridad del catedrático vasco y planean para él una fuga a Portugal, que Unamuno no acepta. Está dispuesto a llevar hasta el final su lucha y sabe que le resultará más eficaz el papel de víctima que el de fugitivo. (Salcedo 1998: 275)

Segundo Emilio Salcedo, quen entrevistou numerosos persoeiros coetáneos de Unamuno, este último presentía que o desterro ${ }^{3}$ poderíase converter nunha especie de "boomerang" para os que planeaban illalo en Fuerteventura xunto co coñecido político republicano Rodrigo Soriano. No seu prólogo ao libro máis coñecido deste último, titulado España bajo el sable, Julio R. Barcos incide nesta mesma idea, con maior énfase:

El confinamiento de Unamuno y Soriano en la inhospitalaria isla de Fuerteventura, fue un gravísimo traspiés del dictador; y el rey que lo consintió, no fue capaz de percatarse, a pesar de su proverbial astucia, que firmaba a plazo fijo su sentencia de muerte. En efecto: las víctimas no iban a tardar en erigirse ante la opinión del mundo en jueces de los verdugos de las libertades públicas de su patria. (Soriano 1931: 7)

Neste sentido, o desterro do antigo reitor da universidade salmantina xunto co simultáneo peche do Ateneo de Madrid mostran unha especie de cambio de paradigma, que Valentín del Arco reflicte con estas palabras:

3 Desde o punto de vista técnico-xurídico, a expresión "confinamento" sería a máis correcta en termos de Dereito Penal. 
La ruptura de la legalidad va a poner en marcha, casi inmediatamente, un proceso de clarificación de la izquierda española que se extiende en un primer momento hasta febrero de 1924 en que, con el destierro de Unamuno y el cierre del Ateneo de Madrid, parece demostrarse la incompatibilidad de la Corona con el modelo de reconstrucción del país pretendido por el liberalismo español. A partir de febrero de 1924 van a abandonarse de alguna manera las soluciones políticas que intentaban el mantenimiento de la Monarquía y tanto Unamuno, que se integrará tras su destierro y posiblemente contra su deseo pero sin otra elección en el grupo que va a aglutinar Blasco Ibáñez en París, como el grupo de intelectuales del interior, iniciarán la lucha que a la larga conducirá a la solución republicana. (1986: 130)

Se nos atemos á atención que o Directorio militar presta ao confinamento de Unamuno, patente no seu expediente gubernativo achado en xullo de 2012, Primo de Rivera debeu darse conta moi axiña da transcendencia que tería esta medida para España, dentro e fóra das súas fronteiras.

\section{Confinamento}

\subsection{Real Orde de desterro}

Ilustrísimo señor: Acordado por el Directorio Militar el destierro a Fuerteventura (Canarias) de don Miguel de Unamuno y Jugo, Su Majestad el Rey (que Dios guarde) se ha servido disponer: Primero: Que el referido señor cese en los cargos de vicerrector de la Universidad de Salamanca y decano de la Facultad de Filosofía y Letras de la misma; y Segundo: Que queda suspenso de empleo y sueldo en el de catedrático de dicha universidad.

Este foi o contido da Real Orde notificada polo Goberno Civil de Salamanca ao Reitor da súa Universidade, o 20 de febreiro de 1924.

Pois ben, Unamuno asina o "ENTERADO"4 desta medida, que lle foi comunicada no seu domicilio mediante un oficio do Coronel Gobernador Civil de Salamanca, ás 20:25 horas daquel infausto mércores 20 de febreiro. Á solicitude da autoridade, o filósofo manifesta por escrito que sairá de Salamanca ás 13:45 do día seguinte, indicando que utilizará Cádiz como porto de embarque para as illas Canarias.
Unha minuta manuscrita do Goberno Civil desa mesma noite do 20 de febreiro pon en coñecemento do Ministerio da Gobernación a notificación efectuada a Unamuno. A delegación gubernativa precisa o itinerario do día seguinte, xoves 21 de febreiro, sinalando que:

Miguel de Unamuno saldrá en tren a las 13,45 horas para Medina del Campo, teniendo previsto enlazar con el rápido de Irún, que le conducirá a Madrid a las 21,10 horas para continuar viaje hacia Sevilla y Cádiz.

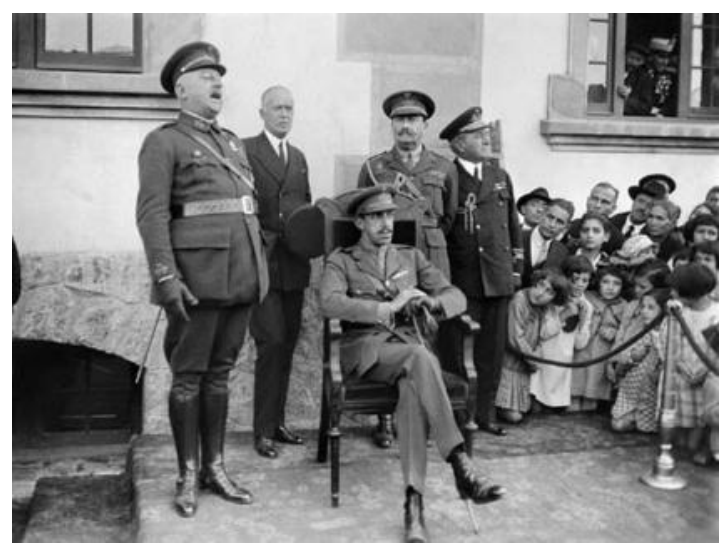

Alfonso XIII escoita sentado a Primo de Rivera

\subsection{Ruta por Madrid, vetada}

Tras recibir esa última comunicación, o director xeral de Seguridade envía o mesmo xoves 21 un telegrama cifrado a Salamanca "ordenando se notifique a Miguel de Unamuno que la ruta hacia el puerto de embarque se efectúe por Cáceres y Sevilla, no consintiendo que se haga por Madrid".

Con todo, unha minuta manuscrita do Goberno Civil salmantino ao Ministerio da Gobernación do mesmo xoves 21 infórmalle que: "En el tren de las 13,45 salió Don Miguel Unamuno (sic) el cual llegará a esa Corte a las 21,10 si en Medina consigue enlazar con rápido Irún".

En segunda nota manuscrita do venres 22 de febreiro de 1924, o Gobernador Civil exonérase de culpa ante a "Dirección General de Seguridad" (DGS) pola ruta que seguiu finalmente Unamuno por Madrid, coas seguintes palabras:

4 Expediente gubernativo del destierro de Miguel de Unamuno (descuberto en 2012, os seus documentos son obxecto de análise nesta parte do traballo), Archivo de la Junta de Castilla y León, https://archivoscastillayleon.jcyl.es/web/ jcyl/ArchivosCastillaYLeon/es/Plantilla100/1284387774505/_ _ _. 
Como primer telegrama sobre D. Miguel Unamuno ( $\mathrm{sic}$ ) no especificaba ruta ni punto de embarque y sí el plazo máximo de 24 horas, la cumplimente (sic), comunicando el día 20 a las 21 ruta y puerto y como quiera que no recibí contestación salió dicho Señor 6 horas antes de recibir su segundo telegrama por lo que no se pudo cumplimentar.

Cal foi a razón pola que a Dirección Xeral de Seguridade quixo impedir que Unamuno fixese escala en Madrid ${ }^{5}$ camiño do seu confinamento? Descoñecémola. Segundo consta no seu expediente de desterro, o Coronel Gobernador Civil de Salamanca foi citado posteriormente polo Subsecretario do Ministerio da Gobernación, sen concretar o asunto, nuns termos sumamente confidenciais: "Debe venir solo y estando relevado de obligación de presentarse a S.M. el Rey o si por atención o conveniencia se presentase al Presidente hacerlo en traje de paisano". Probablemente nesa/s conversa/s saírían á luz os motivos do veto á ruta por Madrid.

Formulamos tres hipóteses sobre o contido do telegrama cifrado de Gobernación, que vetaba a ruta por Madrid:

1) A despedida masiva tributada a Unamuno, en Salamanca, á primeira hora da tarde do día anterior, protagonizada por estudantes e traballadores na plataforma da estación salmantina, con chamamento á folga incluído. $\mathrm{O}$ Directorio militar intentaría evitar así a súa repetición na Estación do Norte madrileña.

2) A escala en Madrid podería amplificar o eco da medida de desterro, cun don Miguel desvalido, rodeado de xornalistas, estudantes, profesores, a carón de persoas opostas ao réxime ditatorial, só cinco meses despois de que Miguel Primo de Rivera chegase ao poder.

3) Se Unamuno desviaba o seu itinerario por Estremadura, como recomendaba a DGS, o seu desprazamento non se vería afectado polo temporal de neve e un choque de trens acontecido vinte e catro horas antes en Navalgrande (Ávila) -feito apenas divulgado, que se explica a continuación- garantindo así o éxito da súa deportación.

\subsection{Choque de trens}

O catedrático "suspendido" Unamuno, vixiado por dous policías, foi acompañado no traxecto ferroviario ata Medina del Campo polos seus colegas de Salamanca Cañizo, Trías e Prieto Carrasco. Só o coñecido tradutor Wenceslao Roces continuará ao seu carón na ruta ata Madrid. Xuntos collerán o rápido de Irún, un tren que facía practicamente toda a Línea Norte: $641 \mathrm{~km}$ desde Hendaya ata a capital do Estado.

$\mathrm{O}$ traxecto do rápido de Irún atravesaba Navalgrande. Un pequeno apeadeiro situado a $102 \mathrm{~km}$ da Corte, que utilizaron 1.542 viaxeiros en 1924, segundo informa a Memoria da "Compañía de Caminos de Hierro del Norte de España" daquel ano. Pois ben, xusto no mesmo día en que Primo de Rivera asinaba o desterro de Unamuno, dous trens (un mixto e outro tranvía) colisionaron naquel punto da liña ferroviaria, polo que tiña que pasar o convoi co intelectual vasco.

Botando unha ollada á hemeroteca do xoves 21 de febreiro de 1924, lemos na edición matinal do $A B C$ unha detallada crónica do accidente ferroviario, asinada en Ávila contra as 9 da noite do día anterior:

...a consecuencia de la aglomeración de nieve, el tren mixto hubo de detenerse en el kilómetro 102, entre las estaciones de La Cañada y Navalgrande, y a poco fue alcanzado por el tren tranvía. El choque fue ya inevitable y violentísimo, tanto, que casi todos los vagones del mixto son un montón de astillas; el de cola saltó a cuatro metros de la vía por encima de la máquina.

$\mathrm{O}$ accidente saldouse con tres vítimas mortais segundo o diario monárquico mencionado, que os xornais El Liberal e Heraldo de Madrid elevaron a catro, co pasamento adicional dun suboficial procedente de Marruecos, que "iba a Salamanca a recoger a su mujer y a sus hijos".

Un solto do diario $A B C$, da edición antes citada, tamén informaba que "en la Dirección General de Seguridad se recibió anoche un parte de la Comandancia de la Estación del Norte dando noticia del siniestro y de haber regresado a Ávila el tren de socorro". Este dato é importante, porque o Directorio militar coñeceu deste xeito que unha colisión ferroviaria desa magnitude podía poñer en risco a primeira parte do desterro de Unamuno.

\subsection{Entre tres e cinco horas de demora}

Así pois, o temporal de neve e o accidente de ferrocarril impediron que don Miguel de 
Unamuno arribase a Madrid ata a madrugada do venres día 22 de febreiro. Nas súas edicións deste día, os xornais El Liberal e El Sol informaron dun atraso da súa chegada de tres horas, que o $A B C$ estendeu ata as dúas da madrugada, case cinco despois das 21:10, horario previsto pola compañía ferroviaria.

Naquela noite tan fría por tantos motivos, El Liberal do mesmo 22 de febreiro achegaba outro dato interesante: "A consecuencia del fuerte temporal reinante se suspendieron por avería en las líneas, las conferencias telefónicas, con Asturias, Galicia, Bilbao, Rioja y Castilla la Vieja". Esta suspensión puido afectar ás comunicacións entre a Dirección Xeral de Seguridade e a delegación gubernativa en Salamanca, permitindo que fora posible a viaxe de Unamuno a través de Madrid.

A pesares das inclemencias meteorolóxicas, a mocidade estudantil madrileña agardaba con esperanza o momento de recibir a Unamuno. A prensa madrileña non mencionará manifestación ningunha de benvida -sometida como estaba á censura militar- pero o testemuño do coruñés Emilio González López, estudante de Dereito na Universidade Central, informa dun chamamento á protesta que foi seguido polos universitarios:

Un grupo de estudiantes tomó el acuerdo de ir a esperar a Unamuno, que estaba en Salamanca. En las paredes de la Universidad apareció el primer llamamiento estudiantil de franca protesta contra la Dictadura. "Estudiantes, decía un cartel colocado al lado de la puerta que hay al final de la escalera central de la Universidad de Madrid, la indigna Dictadura que preside Primo de Rivera ha atropellado a uno de los ciudadanos más preclaros de la patria española: al maestro Miguel de Unamuno. Acudamos todos a la estación del Norte para demostrarle nuestra adhesión, que significa al propio tiempo nuestra protesta contra la Dictadura”. (González López 1931: 67)

\subsection{Ausencia de Jiménez de Asúa e Marañón}

Pois ben, os universitarios madrileños non lle fallaron ao sabio catedrático naquela noite tan crúa, ao dicir de González López:

Y aquella noche, a pesar de la nieve que caía sobre Madrid, se reunió en la estación del Norte un gran grupo de estudiantes, demostrando con su presencia la solidaridad estudiantil hacia el maestro Unamuno. (Ibid.: 67)

O estudante coruñés de Leis na Universidade Central prosegue explicando o que sucedeu

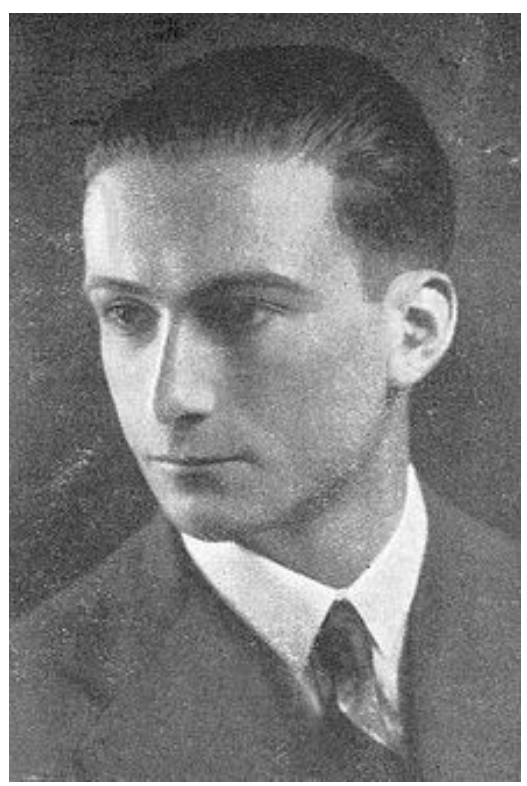

Emilio González López, estudante coruñés en Madrid

poucas horas despois na estación do Mediodía -hoxe coñecida como Atocha-:

Al día siguiente, a eso de las nueve de la mañana pasó por los pasillos de la Facultad de Derecho un estudiante que nos dió la noticia de que Unamuno saldría de Madrid, confinado a Canarias, a los pocos minutos. Algunos estudiantes que íbamos a entrar en clase de Derecho administrativo nos trasladamos apresuradamente a la estación del Mediodía, con tiempo suficiente para poder saludar a Unamuno que estaba rodeado de numerosos amigos. Al poco rato llegaron más estudiantes: eran compañeros de Medicina y, al parecer, vascos de origen. Arrancó el tren, y entre los vivas a Unamuno resonaron los primeros vivas a la libertad que se dieron al aire libre en la época dictatorial. (Ibid.: 68)

Nesta primeira obra titulada El espíritu universitario - publicada cando se proclamou a Segunda República, sete anos despois da Orde de desterro de Unamuno- González López refire que os estudantes de terceiro de Dereito, que acudiran a despedilo a Atocha, regresaran á súa facultade da Universidade Central indignados polo sucedido. Un estado de ánimo trasladado con gritos de "¡Viva Unamuno! ¡Abajo Primo de Rivera" á aula onde impartía clase o penalista Jiménez de Asúa, quen eloxiou daquela a figura de quen fora ata entón vicerreitor da universidade salmantina, ante os seus exaltados alumnos.

Porén, no seu libro posterior Memorias de un estudiante liberal (1903-1931), publicado en 1987, o xurista galego afirmou que: 
los hermanos Esteban y Emilio Mirasol y yo recogimos en su casa al profesor Jiménez de Asúa para ir a la estación de Atocha. Unamuno estaba ya en el tren rodeado de amigos y de policías, que eran casi tantos los unos como los otros. En la estación nos encontramos a D. Gregorio Marañón, Ossorio Gallardo y a Salvador Vila, discípulo de Unamuno en Salamanca, que estaba preparando cátedra de Árabe. Al partir el tren con Unamuno fue despedido con gritos de Viva la libertad! Unamuno parecia conmovido por nuestra despedida.

Partido el tren, la policía nos detuvo a todos los estudiantes allí congregados y nos llevó a la estación de policía de aquel lugar; y como encontraron en posesión de Salvador Vila un libro en árabe, que le servía para preparar sus oposiciones, creyendo que se trataba de alguna clave sospechosa, nos detuvo por más de una hora, hasta que comprendieron que no había tal clave, sino un inocuo libro en árabe. (González López 1987: 127)

A memoria debeu traizoar severamente a González López cando lembraba estes feitos, 63 anos despois de acontecidos, porque o soado penalista Jiménez de Asúa remitíralle carta a Unamuno desde Madrid (C/ Claudio Coello, 102) ese mesmo venres 22 de febreiro de 1924 -recollida por Itziar Fernández Marrón (1998)- escusando a súa ausencia en Atocha nos seguintes termos:

Mi querido y admirado amigo: Como otras muchísimas personas que hubiéramos bajado a la estación a despedirle, he sabido yo con posterioridad a su partida, la hora y el día de su marcha. Por otra parte creo que la policía impidió a los miembros de la Junta del Ateneo (de la que formo parte), ir a rendirle a Vd. este homenaje de solidaridad y simpatía. Pero ya que no me fue posible acompañarle a la salida del tren, le escribo - sin saber si esta carta llegara ( sic) - para que vea en ella una adhesión cordial y una simpatía siempre mantenida a su persona y á sus nobles actitudes. Por José Antón -que fue mi discípulo mejor- he sabido hoy la despedida que se le tributó en Salamnca. De haber sabido aquí la hora de su marcha creo que hubiera sido $\mathrm{Vd}$. despedido con igual emoción. Yo no sé lo que va a pasar en esta desdichada España. (1998: 200-201)

Igualmente ficaría ausente da despedida de Unamuno Gregorio Marañón, se facemos caso á súa carta sen data, enviada desde Madrid (C/ Serrano, 43) a comezos de 1924. Unha misiva -rescatada do esquecemento en 2008 pola Fundación Marañón-Ortega y Gasset-que di así:
Mi muy querido Don Miguel: no sé si estas líneas llegarán a sus manos. Sepa que nos prohibieron a los de la Junta Directiva del Ateneo, verle: no me fue posible, por esto, ir a la estación. Le busqué en Madrid, ya sin tiempo, porque se había ido. He pasado toda la noche, sin acostarme, de la ceca a la meca, trabajando por los ateneístas detenidos por tomar café y tener inteligencia. Con todo el dolor de mi corazón y el cariño y entusiasmo de siempre le abraza MARAÑÓN. Su retrato está en un lugar preferente de mi despacho, para que el mundo lo vea, como al de un padre, que lo es Ud. de todos. (López Vega 2008: 112)

Quizais pola precipitación daquelas horas, o mozo coruñés alumno de Dereito non se decatou da presenza na estación de Atocha dos doutores Goyanes Capdevila e Madinaveitia Ortiz de Zárate, quen daquela contaban con 48 e 63 anos respectivamente, aos que logo nos referiremos. Pode ser que o estudante galego oíse falar da presenza dalgúns médicos, e supuxo que o Dr. Gregorio Marañón asistira á concentración de despedida a Unamuno na estación do Mediodía. Tamén se trabucou mencionando a Jiménez de Asúa. Pola contra, outra fonte que logo sinalaremos acreditou a presenza na estación do político Ángel Ossorio y Gallardo, avogado de Unamuno, testemuñando tamén a presenza de estudantes vascos.

Con todo, as cartas de Jiménez de Asúa e Marañón subliñan as medidas represivas implantadas polo Directorio militar para silenciar as adhesións a Unamuno, asoballando a contestación organizada polos ateneístas madrileños. Non en balde, como deixou escrito o propio González López: "del Ateneo de Madrid, hogar de nuestra intelectualidad, la entidad que había llevado tan certeramente la campaña en pro de las responsabilidades por los desastres españoles en Marruecos, salieron los primeros ataques contra ella (la Dictadura)" (1931: 65).

\subsection{Sen diñeiro no peto}

Despedido con gritos de "¡Viva la libertad!" na estación de Atocha, camiño de Sevilla, como reflectiu Emilio González López, unha longa viaxe agardaba aínda ao catedrático de Salamanca.

Con 59 anos de idade ás súas costas, Unamuno disporía entón de tempo sobrado para pensar no futuro que lle agardaba á súa familia: a súa esposa Concepción Lizárraga e a súa numerosa prole, cuxo sustento principal proviña da súa retribución universitaria, agora suspendida. 
Chegado a Cádiz, agardará oito interminables xornadas polo barco que debería conducilo ata ao arquipélago canario. $\mathrm{O}$ seu biógrafo Emilio Salcedo reproduciu así o momento previo ao seu embarque:

La dirección del Hotel le pasa la cuenta y don Miguel enrojece y con voz aguda, llameándole los ojos azules tras los espejuelos de sus gafas, señala a los policías. Que paguen esos, que sabrán por qué me traen.

Unamuno no lleva ni un céntimo en el bolsillo. Al salir de Salamanca lo hizo con unas dos mil pesetas, casi una fortuna para entonces; pera cuando Aldecoa fue a llevarle el cheque en blanco de Echevarrieta ${ }^{6}$, lo pensó mejor y le entregó este dinero para que lo remitiera a su mujer en Salamanca (Salcedo 1998: 277)

\subsection{Dúas versións}

Porén, hai outra versión do acontecido no hotel gaditano, diferente á expresada por Emilio Salcedo. Segundo desvelou no xornal Deia do 2 de xuño de 2018 Arturo Aldecoa Ruiz, neto de Juan Antonio Aldecoa, home de confianza do magnate vasco Echevarrieta, o diario de seu avó recolle esta anotación do día 25 de febreiro de 19247:

Por la mañana he estado en el Hotel Suizo (Duque de Tetuán 33 Cádiz) llamado por el Sr. Don Miguel Unamuno (que está allí de paso para su deportación a Canarias) y me ha entregado en depósito un sobre conteniendo 2.700 pesetas (dos mil setecientas), contra un recibo que poco más o menos dice: "He recibido de Don Miguel Unamuno en calidad de depósito la cantidad de dos mil setecientas pesetas (2700) que están a su disposición a la vista. Cádiz 25 de febrero de 1924. (...) El sobre se devolverá contra entrega del recibo mío o de otro que lo anule". (p. 13)

Proseguía o artigo de Deia indicando que:

Aldecoa no recibió orden de Unamuno y, según el diario, tuvo guardado el dinero hasta 1930.

¿Y la familia sin recursos? Unamuno, contra toda lógica y al contrario de lo que se divulgó, no da a Aldecoa el dinero para que lo remita a su esposa en Salamanca (mujer y seis hijos, dependientes de su sueldo, entonces suspendido). Pero afortunadamente y de forma paralela al destierro, la familia de Unamuno no queda abandonada, pues recibe ayuda de curiosas fuentes, incluido un coro de médicos y una casual participación del gordo de Navidad de 1924. ¿Suerte?

O neto de Juan Aldecoa preguntábase a continuación retoricamente:

¿Qué hubiera pasado si Unamuno sí hubiera aceptado la ayuda de Echevarrieta? ¿Lo hubieran reconocido en público? Lo cierto es que a Unamuno el reconocer que aceptaba ayuda de un amigo no le hubiera gustado, pues de alguna forma significaba desdecirse de sus palabras. Tampoco a Echevarrieta le habría gustado la aceptación pública de la ayuda, pues podría traerle problemas más adelante con el Gobierno si el destierro de Unamuno se complicaba.

Así que al rechazar públicamente Unamuno la ayuda de Echevarrieta (y bien se preocuparon ambos de que tal rechazo se conociera) los dos salían reforzados. Pero, ¿de verdad se rechazó la ayuda?

No seu prólogo de 1998 ao libro de Unamuno Alrededor del estilo, o tamén catedrático salmantino xa desaparecido Laureano Robles Carcedo menciona que o intelectual vasco rexeitou o diñeiro que lle ofrecera $\mathrm{M}$. Herriot, en nome do Goberno francés. Robles Carcedo debeu basearse nunha carta de don Miguel a Castañeyra Schamann, de decembro de 1924, na que recordaba esta oferta de Herriot, que agradeceu "sin haberlo necesitado aún", sen que a misiva especifique o momento exacto en que recibiu esa oferta do Goberno francés $(\mathrm{Ca}-$ sa Museo Miguel de Unamuno, 104, 22, 003).

\subsection{Puerto Cabras}

Desde Cádiz, o periplo do desterro levaría a Unamuno ata Las Palmas de Gran Canaria. Alí permaneceu outra semana máis, agardando polo buque que o trasladase a Fuerteventura,

6 Juan Aldecoa era o representante do navieiro vasco Horacio Echevarrieta nos estaleiros de Cádiz. Como filántropo, este magnate vasco, que foi deputado republicano, iniciou con 10.000 pesetas a suscrición popular para doar $L a$ Virgen del caballero de Montesa, de Paolo de San Leocadio, ao Museo do Prado, no ano 1919, multiplicando o mecenado das propias Casa Real e de Alba. Pero Miguel de Unamuno mantivera as distancias desde tempo atrás con este multimillonario, cando se reclamaba liberal, segundo lle contara nunha carta moi expresiva ao ilustre filólogo bilbaíno Pedro de Múgica, datada o 6 de marzo de 1893: “Ahora estoy metido en campaña electoral. Desde aquí mando artículos a El Nervión acerca de las nuevas elecciones municipales, contra la política, allí hay negocio; se trata de que Echevarrieta, Chávarri, Salaegui y Cía. se apoderen de Bilbao so capa de ideales políticos" (Fernández Larraín 1972: 170-171).

7 https://www.deia.eus/actualidad/historias-de-los-vascos/2018/06/02/unamuno-echevarrieta-amigos/652212.html. 
xunto ao político federalista radical Rodrigo Soriano ${ }^{8}$.

O confinamento definitivo de ambos opositores á Ditadura tería lugar en Puerto Cabras, apenas un caserío por entón, hoxe convertido en Puerto del Rosario, a capital de Fuerteventura.

O catedrático de Grego deportado chegaría ao seu lugar de desterro, entre 19 e 21 días despois de saír de Salamanca -1924 foi ano bisesto-, variando a cifra segundo as fontes consultadas.

$\mathrm{Na}$ illa do vento permanecería cerca de catro meses. Neste período, segundo o Epistolario galego de Miguel de Unamuno, obra do profesor Alexandre Rodríguez Guerra (2000), un sete por cento dos galegos que mantiveron correspondencia co soado persoeiro ao longo da súa vida manifestaríanlle a súa solidariedade por escrito. Rodríguez Guerra cita, por orde alfabética do seu primeiro apelido, as seguintes persoas: G. Albarrán Puente, F. Luis Bernárdez, E. Botana, D. Díaz, V. García Riego, M. Margolles, A. Martínez, A. Revilla e R. M. Tenreiro.

Grazas ás mensaxes de alento, chegadas da península e do estranxeiro, pero tamén co apoio das xentes de Fuerteventura, a paisaxe árida, inhóspita, "acamellada" -como a cualificaría don Miguel- tornaríase acolledora, hospitalaria e receptiva, para o destituído vicerreitor da Universidade de Salamanca.

Naquel tempo, entre as "forzas vivas" de Fuerteventura, salientaba unha familia de orixe galega chamada Castañeyra (con y grego), que trocara o seu apelido orixinal Castañeira (con $i$ latino). Pois ben, deles sería hóspede Unamuno nesta terra de desterro e asilo, que ao longo da súa historia acollería máis tarde a anarquistas como Buenaventura Durruti ${ }^{9}$. Pero tamén a deportados da seguinte ditadura española do século XX, como Fernando Álvarez de Miranda, Joaquín Satrústegui e Vicente Miralles,

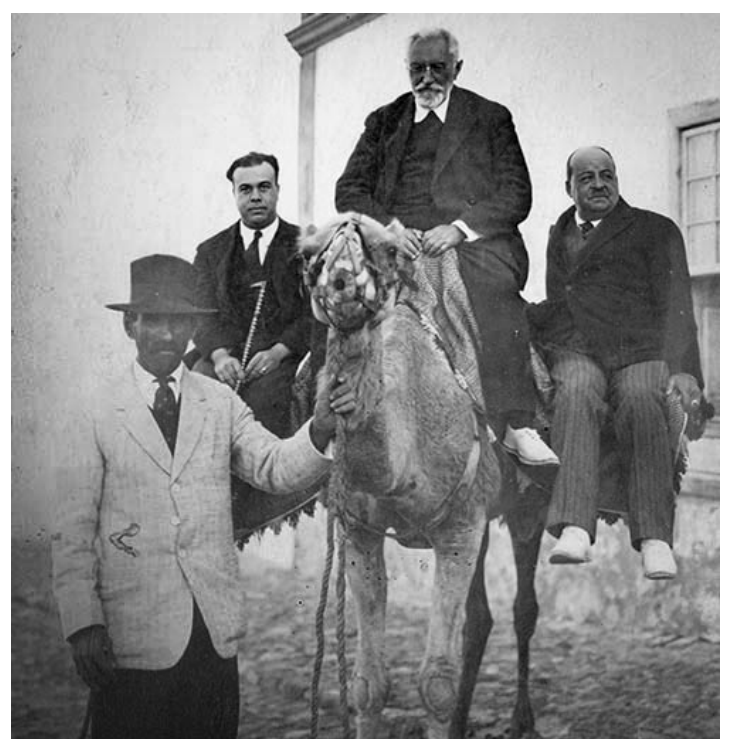

Unamuno ao lombo dun dromedario. A súa beira, Soriano e Castañeyra, quen porta bastón

implicados no "contubernio de Múnich" (denominación esta aplicada polo franquismo ao cuarto congreso do Movemento Europeo, celebrado na capital bávara no ano 1962).

\subsection{Os Castañeyra: "dramatis personae"}

Os "anfitrións" principais de Unamuno en Fuerteventura tiñan raíces lucenses. A árbore xenealóxica dos Castañeyra mestura empresarios, políticos, militares, diplomáticos, xuíces e mesmo xornalistas por espazo de cinco xeracións.

Unha saga iniciada polo sarxento de Carabineiros Xosé Fernández Castiñeira (18191888), quen nacera en Mondoñedo (Lugo) como fillo lexítimo de Lorenzo e Juana, chegando a Puerto Cabras no ano 1850. "No sabemos en qué momento ni en virtud de qué accidentes, el primer Castañeyra cambia de planes e inagura sus operaciones mercantiles (...) en un puerto habilitado de reciente creación" (Millares 1979: 89).

\footnotetext{
Por recomendación paterna, o empresario Ramón Castañeyra Schamann (1896-1973), delegado gubernativo en Fuerteventura co rei Alfonso XIII ata o ano 1923, acudiu a recibilo a Las Palmas, trasladándose ao seu carón a Puerto Cabras a continuación.

9 Segundo o testemuño que Ramón Castañeyra Schamann, "home forte" desa familia, lle escribiu a un solicitante de información chamado Abel Paz, o seu irmán Benxamín, mariño mercante de profesión, salvou a vida o 20 de xullo de 1936 grazas aos bos oficios de Buenaventura Durruti: “...mi hermano llegó a Barcelona, en el Villa de Madrid el 20 de julio de 1936; y se vio acusado de fascista por uno de los camareros del buque, se acordó de que nos había visto conversar y se dirigió a él expresándole que era hermano mío. Fue suficiente para que Durruti le colocara en una casa de confianza, evitándole el paseo terminal". O xefe anarquista intercedeu para evitar a súa execución, lembrando a hospitalidade que lle prestara Ramón, prestándolle libros durante o seu confinamento de catro meses en Fuerteventura no ano 1932. Véxase ao respecto o artigo de Rodríguez Rodríguez 2013.
} 
O único fillo varón do suboficial, chamado Ramón F. Castañeyra (1844-1917) abandonou o primeiro dos seus apelidos substituíndoo por un $F$. Exerceu de alcalde de Puerto Cabras, foi administrador de portos francos, pero tamén home de negocios e masón ${ }^{10}$.

No seu prólogo ao libro de Ramón F. Castañeyra titulado Memoria sobre las costumbres de Fuerteventura (1991), o historiador Francisco Navarro Artiles ${ }^{11}$ describe o eixo sobre o que pivotaba a actividade comercial das súas empresas:

...importar productos del exterior (entre ellos coloniales), venderlos a sus clientes (prácticamente todos los habitantes de la Isla); cobrar en productos del país (trigo, cebada, barrilla - especie vegetal de la que obtenían sosa caústica para hacer jabón- cochinilla -insecto con el que producir colorantes-) y exportar estos productos al resto de Canarias, a la Península y al extranjero.

Cabeza da terceira xeración desta familia $m a-$ jorera foi José Castañeyra Carballo -con el desaparece o F. do apelido Fernández nesta saga-, igualmente alcalde de Puerto de Cabras, fundou e dirixiu ademais o xornal La Aurora (1902-1906), presidido por Ramón F. Castañeyra. Foi membro da sociedade de aguas "La Esperanza" e vicepresidente do casino "El porvenir" -tres sociedades con nomes de claras resonancias masónicas. José Castañeyra, quen estaba considerado un dos maiores contribuíntes da capital de Fuerteventura, falecería nos anos 30 do século pasado.

O maior dos vástagos de José Castañeyra resultou ser Ramón Castañeyra Schamann, comerciante adiñeirado, delegado gubernativo da Monarquía na illa de Fuerteventura ata a proclamación da Ditadura. Nado en 1896 e falecido en 1973, recibiu en Las Palmas de Gran Canaria a Unamuno, por indicación familiar, acompañándoo despois ata Puerto Cabras.

Ramón Castañeyra Schamann foi herdeiro universal do seu avó Ramón F. Castañeyra -segundo nos informou o sobriño neto deste último, Lorenzo Mateo Castañeyra. Ambos Ramóns conviviron xuntos nunha morada xa desaparecida, que atesouraba unha biblioteca con máis de 600 libros, entre eles volumes dedicados polos seus autores e numerosas "edicións príncipe". O Cabildo de Fuerteventura entregou 300 dos devanditos libros no ano 2018 ao Concello de Puerto del Rosario, que xa contaba con outros tantos (Cerdeña Armas 2011).

\subsection{A biblioteca de Unamuno e Durruti}

Entre as persoas que recorreron aos fondos da nutrida biblioteca Castañeyra, estiveron don Miguel de Unamuno e oito anos máis tarde Buenaventura Durruti, tamén confinado en Fuerteventura. O pensador bilbaíno puido afondar así nas obras de don Benito Pérez Galdós. "Nunca podré olvidar que fue ahí y gracias usted y a su librería, que releí a Galdós y aprendí a conocerle...", escribiralle nunha carta posterior a Ramón Castañeyra Schamann, da que dará conta a súa sobriña Encarnación de la Fe Castañeyra, nun escrito ao que logo nos referiremos.

Segundo certas versións, no exterior daquela morada tan literaria celebraban tertulia cara ao mar Unamuno e Soriano. Cando a discusión

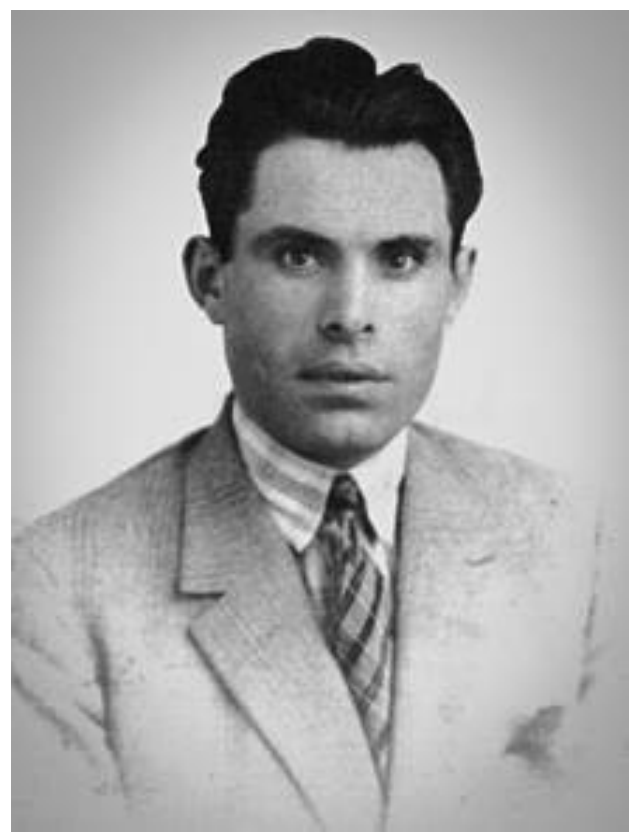

O líder anarquista Buenaventura Durruti

10 Véxase De Paz Sánchez 1984. Ramón Fernández Castañeyra aparece co nome simbólico de Nivar, coa ocupación de comerciante. Pertenceu a dúas loxas masónicas, con diversidade de graos, xa que os "irmáns" das illas canarias máis orientais acabaron creando o seu propio taller. A primeira, chamada loxa Teide, estaba radicada en Santa Cruz de Tenerife e a segunda, Atlántida ${ }^{\circ}$ 92, en Arrecife de Lanzarote. Esta última, baixo os auspicios da loxa nai en Lisboa.

11 Cf. Navarro Artiles 1980. 
subía de ton entre os dous confinados, Ramón Castañeyra interviña como moderador. No grupo integrábanse tamén o crego Víctor San Martín, párroco de San Bartolomé, e o pousadeiro Francisco Medina Berriel -tres de cuxos fillos emparentarían despois con outros tantos descendentes de Ramón Castañeyra Schamann.

Co motivo da chegada de Unamuno á illa, a familia Castañeyra decidira manter alugada ao citado "Paco" Medina Berriel unha casa da súa propiedade, que pensaran pechar inicialmente, pomposamente chamada "Hotel Fuerteventura" - dato que nos foi relatado por Lorenzo Mateo Castañeyra, sobriño neto de Ramón Castañeyra Schamann. Esta residencia foi o lugar onde se aloxaron Unamuno e Soriano cando pousaron os seus pés en Puerto Cabras.

Segundo o filólogo canario Francisco Navarro Artiles, o aloxamento "estaba orientado al naciente y le daba el sol al amanecer", tal como reflectiu o propio Unamuno no artigo "Los reinos de Fuerteventura" o 16 de maio de 1924: "en estas mañanas, cuando el sol al salir de la mar, me da, recién nacido, un beso en la frente".

Logo de semanas de tensión, comezou unha etapa de acougo para os desterrados. Segundo o matrimonio Rabaté, ambos biógrafos de Unamuno:

éste se siente cada vez más atraído por esas Hurdes marítimas, por ese pedazo de África sumido en el Atlántico. También aprecia a los habitantes que son un tesoro de nobleza, lo acogen bien el notario, el juez e incluso los militares, y por eso los primeros días en Fuerteventura tienen más sabor a vacaciones que a destierro. (2013: 15).

Diversas instantáneas mostran naqueles días a Ramón Castañeyra Schamann á beira de don Miguel de Unamuno e Rodrigo Soriano, sexa en Puerto Cabras ou durante as súas excursións por Fuerteventura. Ramón era home de baixa estatura, máis ben groso, que aparenta nas fotografías máis idade dos 28 anos que tiña cando acolleu o intelectual deportado. Castañeyra Schamann era unha persoa moi influída polo seu avó, o homónimo Ramón F. Castañeyra. Con só trece anos escribira Cantares, un libro que recolle poemas e cancións populares de Fuerteventura, prologado nunha edición de 2003 pola súa sobriña Encarna Castañeyra de la $\mathrm{Fe}$, quen foi a primeira muller xuíza de Fuerteventura.

\section{3. "Nunca camiñarás só"}

\subsection{Un encontro premeditado}

Chega o momento de preguntarse por que tivo tantos xestos de atención Ramón Castañeyra Schamann con Unamuno. Pois ben, "este encontro entre Unamuno e Castañeyra foi premeditado", segundo desvelou nunha entrevista o investigador canario Elías Rodríguez Rodríguez falecido en xaneiro de 2018 (Pérez 2017).

Vistas con perspectiva, as palabras do investigador majorero cobran importancia senlleira, porque tivera acceso a unha documentación fundamental. Trátase das cartas e papeis de Rodrigo Soriano, que lle foran enviados pola súa filla desde Chile, onde fora embaixador da Segunda República, antes de que ela mesma falecese en 2016. Soriano, quen era todo un persoeiro, fora confinado polo Directorio militar en Fuerteventura xunto a Unamuno, no ano 1924. Indagamos na razón.

\subsection{O bravo Rodrigo Soriano}

Para quen descoñeza a historia de Rodrigo Soriano Barroeta-Aldamar, sinalaremos que este radical federalista vasco pertencía a unha rancia estirpe aristócratica, entre cuxos antergos figuraba a princesa de Éboli.

Coñecido librepensador, renunciou aos seus títulos nobiliarios polas súas crenzas próximas á francmasonería. Fillo de Benito Soriano - quen fora director do Museo do Prado-, amigo de Monet e Rodin, dono de varios xornais, deputado en diferentes lexislaturas, Soriano foi por riba de todo un polemista.

Nas entretidas memorias do ordenanza do Ateneo de Madrid Juan Martínez Gómez "Juanito", este recorda entrar no seu salón de actos, cando este home singular chamado Rodrigo Soriano remataba unha alocución con estas palabras "i ...después de esto, a la cárcel!".

Segundo menciona o prologuista de Soriano, Julio R. Barcos, "hubo de batirse, varias veces, por defender sus ideas, ya con Primo de Rivera, con Sánchez Guerra, con el hijo de Maura, con el general Linares, ministro de Guerra y con otros varios personajes" (Soriano 1931: 10). No seu lance con Primo de Rivera, ambos duelistas resultaran feridos. Primeiro o militar no rostro. Logo, o político nunha man.

Rodrigo Soriano referiuse ao seu duelo con Miguel Primo de Rivera nunha conferencia titulada "Ayer, hoy y mañana" (22), ditada no Ateneo de Madrid o 7 de novembro de 


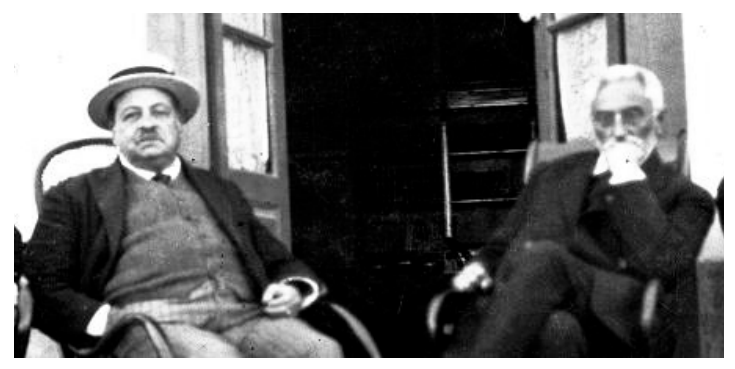

Miguel de Unamuno e Rodrigo Soriano en Fuerteventura

$1923^{12}$ (o Directorio militar proclamárase o 15 de setembro previo):

Libertad reclamo, libertad pido -proclamou-. Yo nunca, jamás, me resignaré a perderla (...) y yo, modesta y sencillamente, os digo que si por perderla debiera perder mi vida, aquí la ofrezco, se la brindo caballeroso con igual hidalguía, a quien en lejano día y en personal lance grave de mi historia política, puse, tan noblemente como él me puso, en trance de perder la suya"

Para sinalar máis adiante:

El señor general Primo de Rivera, inteligente, soleado, efusivo, es un dictador a la andaluza, a la jerezana. (Risas). Ingenuo, noblote, no persigue el interés ni lo expresó nunca en sus cartas al Sr. Alba, aún cuando quedan algunas inéditas. (...) Y mucho me temo - decía yo- que este dictador español, antes del plazo de noventa días, sea un político más a la española y le tome el gusto al poder, y tenga los defectos, las gratas cualidades, de la política vieja, el tuteo y la amena tertulia.

O prognóstico do donostiarra Rodrigo Soriano foi acertado. O xeneral Primo de Rivera traizoou a súa promesa de permanecer no poder 90 días, como afirmara cando dera o seu golpe de Estado. Mais o seu exitoso vaticinio custoulle caro a Soriano. Dezasete anos despois de baterse co militar, unha vez convertido Primo en ditador, foi deportado sen reparo ningún a Fuerteventura, para facer compañía a Miguel de Unamuno.

\subsection{Victoria Castañeyra Schamann, un ne- xo clave}

Cando Unamuno e Soriano chegan ás illas afortunadas, prodúcese ese encontro premeditado entre o catedrático vasco e Castañeyra, do que falou case postumamente Elías Rodríguez Rodríguez. Segundo este historiador majorero, o médico que operara en Madrid a Victoria Castañeyra Schamann, irmá de Ramón Castañeyra Schamann, pediulle por favor ao pai de ambos que atendera en todo o posible a Unamuno, cando foi desterrado ás Canarias.

Por tal motivo, José F. Castañeyra encomendoulle ao seu fillo Ramón converterse no anfitrión do filósofo vasco. Na entrevista virtual que lle fixeron en novembro de 2017 a Elías Rodríguez, este investigador canario non revelaba a fonte da súa información, nin tampouco o nome do cirurxián, pero engadía o dato de que ese doutor vivira posteriormente en Tenerife.

Pola súa banda, Lorenzo Mateo Castañeyra, sobriño neto de Ramón Castañeyra Schamann, completounos os datos ofrecidos naquela entrevista por Elías Rodríguez Rodríguez, que encaixan como unha luva coa versión do investigador tristemente finado. Segundo o seu testemuño:

Una hermana de Ramón Castañeira Schamann llamada Victoria requirió de cuidados especiales cuando era adolescente, al haberle aparecido un bulto en la cadera. Por consejo de unos médicos de Las Palmas, su padre, José Castañeyra Carballo decidió llevarla a Madrid para ser operada.

Padre e hija, acompañadas por una señora de Fuerteventura, coincidieron en la sala de espera de la consulta del cirujano, radicada en la madrileña calle Montera, con Miguel de Unamuno. El progenitor entabló entonces conversación con el intelectual, en la que hablaron sobre una

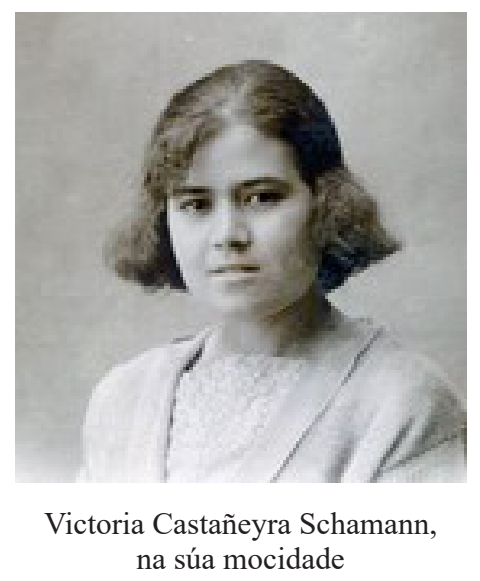
na súa mocidade

12 A conferencia de Soriano orixinou un tour de force da Dirección Xeral de Orde Pública coa Xunta de Goberno do Ateneo de Madrid. O director xeral Miguel Arlegui dispuxo que o centro debía informar das súas reunións, con 24 horas de anticipación, para que estivese presente nelas un delegado da súa autoridade, a partires do 9 de novembro. 
visita que había realizado don Miguel a Gran Canaria. Posteriormente, los tres isleños acudieron a comer al restaurante "Lhardy", de la Carrera de San Jerónimo, distante unos trescientos metros de la consulta. Allí volvieron a coincidir con Unamuno, sentándose todos juntos a almorzar. En ese momento, es de suponer que José Castañeyra Carballo intercambiara su dirección con el pensador bilbaíno ${ }^{13}$.

De maneira que Victoria, cuxa intervención cirúrxica terminou felizmente, foi o nexo clave dunha cadea que enlazaría Unamuno cos Castañeyra.

\subsection{A reprimenda de Goyanes}

Unha carta a don Miguel de Unamuno do Dr. José Goyanes Capdevila confirma que foi o intermediario entre o intelectual deportado e a familia Castañeyra ${ }^{14}$. Fotocopia desta epístola apareceu por primeira vez publicada, sen comentario ningún, na tese de doutoramento Goyanes. Aspectos histórico-biográficos. Este traballo académico foi lido en 1970 polo Dr. Francisco Barreiro Álvarez, ante un tribunal da Universidade Complutense de Madrid ${ }^{15}$.

Posteriormente, a mesma carta recibiu tratamento editorial na obra Epistolario galego de Miguel de Unamuno (Rodríguez Guerra 2000: 306-307), que tamén contén unha referencia sobre este prestixioso cirurxián chamado José Goyanes Capdevila, natural de Monforte de Lemos (Lugo) -onde ten bautizada unha praza co seu nome- e que acabou morrendo en Tenerife -como certeiramente apuntara o profesor Elías Rodríguez Rodríguez.

A carta do doutor Goyanes Capdevila, datada o 7 de marzo de 1930, é toda unha revelación, porque contén unha reprimenda en toda regra a don Miguel de Unamuno cando este se atopaba

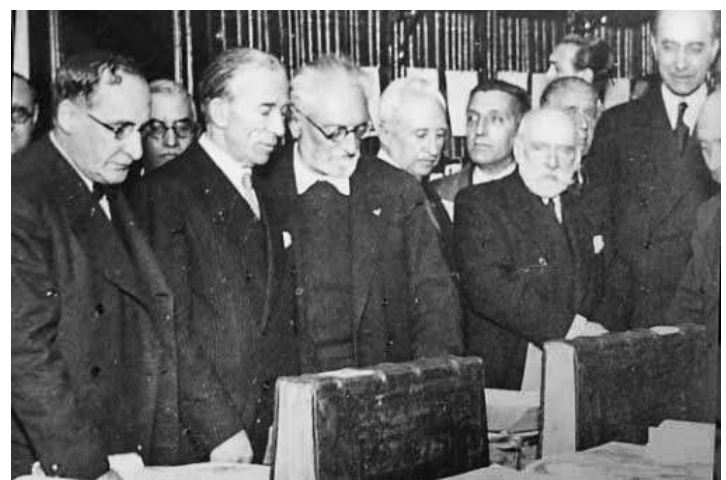

Don Miguel de Unamuno y Jugo revisa uns libros xunto ao Dr. José Goyanes Capdevila

en Hendaya, a punto de volver do seu autoexilio a territorio español. Vexamos a causa, reproducindo o manuscrito da epístola, conservado na Casa Museo de Unamuno en Salamanca:

Dr. J. Goyanes. Príncipe de Vergara, 88

Particular

Sr. Dn. Miguel de Unamuno

Querido Dn. Miguel: reciba V. mi cordial parabien por su regreso á España libre ya de las trabas de la dictadura. Por la prensa me enteré de su telegrama al Sr. Castañeyra, recordando las atenciones que dicho Sr. le prestó durante el destierro en Fuerteventura. Como recuerdo del éxito no me parece mal; pero debo decirle que el Sr. Castañeyra y sus secuaces explotaron indecorosamente su confinamiento para exigir el pago de 6.000 p\$ á sus amigos de aquí de Madrid, y no contentos con ello dicho Sr. me demandó á los tribunales y exigió el pago de otras $3.000 \mathrm{p} \$$ que tuve que abonar, por servicios a V. prestados en Puerto de Cabras. Solo el Sr. Ossorio y Gallardo conoce esta indigna comedia del Sr. Castañeyra, y hoy le escribo á V. para que lo sepa y juzgue de la conducta de esos Señores á quien V. se declara reconocido.

13 Entrevistas telefónicas gravadas, coa súa autorización, a Lorenzo Mateo Castañeyra, sobriño neto de Ramón Castañeyra Schamann, en xuño de 2019. Na última delas, mencionounos que a familia Castañeyra falaba dun médico chamado "Goyanes", con frecuencia.

14 Unamuno e Goyanes foron amigos. Coñecéronse grazas ao catedrático salmantino Agustín del Cañizo. Compartiron excursións pola serra de Guadarrana e consérvase unha instantánea, onde aparecen falando xuntos, diante dunha morea de libros.

15 A citada fotocopia figura, sen paxinar, no traballo académico do doutor de orixe galega Francisco Barreiro Álvarez, quen exerceu como xefe do servizo de Cirurxía Xeral do Hospital La Paz. A tese Goyanes. Aspectos histórico-biográficos foi lida o 15 de xaneiro de 1970 ante un tribunal da UCM presidido polo Dr. Orts Llorca, cos profesores Laín Entralgo, Fernández Ortiz, Gallego Fernández e Poullón Ramírez. Resultou cualificada cun sobresaliente cum laude. Laín Entralgo foi o director desta tese, pero tamén o seu impulsor, segundo explica o doutor Barreiro no texto. O coñecido médico, falanxista na súa primera hora e liberal despois, tamén animara no seu momento a Emilio Salcedo a escribir a súa coñecida Vida de don Miguel, foi prologuista da Vida y obra del Dr. Madinaveitia, obra do doutor Zulaika, profesor de Marañón e colega de Goyanes, participando nunha homenaxe rendida a este último en Madrid, polo ano 1964. 
Que se halle bien entre los suyos le desea su affmo. amigo que le aprecia

\section{J. Goyanes \\ 7 marzo 1930}

En nota a rodapé, o profesor Rodríguez Guerra, que recompilou o epistolario galego de Unamuno, salienta que "o primeiro que fixo Unamuno ó cruza-la fronteira o 9-II-1930 foi poñerlle un telegrama de agradecemento ó alcalde de Fuerteventura". Segundo a nosa pescuda, o Alcalde de Puerto de Cabras nesa época era Ramón Peñate Castañeyra, outro comerciante máis da saga procedente de Galicia.

\subsection{Un conflito entre paisanos}

Como pode verse, a común orixe lucense de Goyanes e Castañeyra (oriúndos de Monforte de Lemos e Mondoñedo, respectivamente) non impediu o conflito entre ambos. Para probar a veracidade das súas acusacións contra o anfitrión de Unamuno, o cirurxián de Monforte de Lemos remitíase á palabra de don Ángel Ossorio y Gallardo, ministro de Fomento con Antonio Maura en 1919, deputado e embaixador coa Segunda República en Francia, Bélxica e Arxentina.

Ossorio y Gallardo tamén ocupara a presidencia do Ateneo de Madrid e o decanato do Colexio de Avogados da capital de España. Esta última corporación rehabilitouno o 30 de decembro de 2015, xunto a sesenta letrados máis, que foran expulsados da institución en 1939 por pertencer ou simpatizar coa masonería.

A severa epístola do doutor Goyanes Capdevila poñía nun brete a Unamuno. Por unha banda, o intelectual bilbaíno sempre defendera que o seu confinamento debía ser ás costas do Estado. Pola outra, don Miguel dedicáralle a Ramón Castañeyra Schamann o seu diario vertido en sonetos De Fuerteventura a París, que foi publicado por primeira vez pola editorial Excelsior en París, no ano 1925. Unha misiva súa a Castañeyra Schamann prologa a primeira parte do volume, precedendo aos 66 sonetos redactados en Fuerteventura. Afectou a Unamuno esta carta posterior do doutor Goyanes, que levantaba serios interrogantes sobre o seu anfitrión na illa do vento?

\subsection{A discordancia biográfica}

Baixo o meu punto de vista, a referida epístola será a clave dunha discordancia biográfica de Unamuno. Na súa carta a Ramón Castañeyra
Shamann que prologa a primeira parte do libro De Fuerteventura a París, Unamuno aseguráballe textualmente: "Les prometí a ustedes volver a esa isla, y si Dios, el de mi España, me da vida y salud volveré. Volveré con el cuerpo, porque con el alma sigo ahí".

Pois ben, Don Miguel nunca pisou Fuerteventura, tralo seu retorno triunfal á terra española en 1930. Polo contrario, si que volveu a París, sen ningún compromiso previo por escrito. Con todo, a correspondencia entre Unamuno e Ramón Castañeyra demostra o interese común de ambos nese retorno.

Para afondar neste punto, analizamos as epístolas intercambiadas entre Unamuno e Castañeyra, que obran en poder da Casa Museo de Unamuno de Salamanca. No seu arquivo, hai fotografía dixitalizada dunha misiva manuscrita remitida polo Reitor salmantino a Ramón Castañeyra do 22 de abril de 1936. Do contexto das cartas de Ramón Castañeyra a Unamuno despréndese que houbo, polo menos, outras dúas deste último: unha con data de 29 de decembro de 1924 -transcrita mecanograficamente no citado arquivo- e outra sen datar, de 1932, á que aludiremos máis adiante, que a súa sobriña Encarnación Castañeyra de la Fe situou cronoloxicamente o día 12 de abril de 1932, polo que debeu ter acceso ao documento (Castañeyra Schamann 2003: 4).

Pola súa banda, a Casa Museo de Unamuno tamén conserva seis cartas e sete telegramas enviados por Castañeyra a Unamuno. Do contexto dunha das misivas despréndese que existiría unha sétima, de mediados de novembro de 1924, que non se atopa no seu arquivo.

Polo menos en dúas ocasións, Ramón Castañeyra Schamann pregoulle a Unamuno que regresase a Fuerteventura. Así o puxo de manifiesto na segunda das súas cartas existente na Casa Museo, datada o 20 de febreiro de 1925, cando Unamuno se atopaba expatriado en París: "Todos esperamos confiadamente que cumplirá Vd. su promesa de volver a esta. ¿Cuándo llegará ese día tan deseado?. ¡Solo Dios lo sabe!" (CMU 11, 116, 002).

Noutra carta sen datar de 1932, Ramón Castañeyra responde unha densa misiva de Unamuno, salientándolle:

Acaricio la idea esperanzada de verle y quiera Dios que sea pronto; bien porque pueda V. realizar su ensueño por mi tan anhelado; o, caso de no ser esto posible, haré cuanto pueda de mi parte por emprender un viaje a esa península para estar unos días con V. y volver a abrazarle con 
análoga emoción a la que lo hice el 9 de julio de 1924 -va a hacer muy pronto ocho años- al despedirnos en Playa blanca. (CMU 11, 116, 4, 002)

Pola súa parte, Unamuno respondeu a esa insistencia na carta remitida a Castañeyra o 22 de abril de 1936: "Cuanto (sic) me acuerdo de su bendita isla! Cuantas (sic) veces pienso que estaría mejor ahí, en Puerto Cabras, o en la Oliva, o en Pájara, o en la Antigua, o en Betancuria... Cuando (sic) podré volver a (ilexible) eso y a darle un abrazo ahí!?" (CMU 11, 116). Con todo, don Miguel non retornou a Fuerteventura.

Facemos aquí un inciso para sinalar que nesta última carta a Ramón Castañeyra de 1936, hai unha acotación interesante de Unamuno sobre Rodrigo Soriano, o seu compañeiro de confinamento:

Una cosa quiero decirle. Usted sabe que apenas salí de ahí rompí, por motivos que quiero olvidar, con Soriano. No volvimos a tratarnos. Pero he de decirle que le mandaron, como usted sabe, a Chile, y que allí como Embajador, ha sabido captarse las simpatías de los chilenos y de la colonia española. Aleccionado -y escarmentado- por la vida ha sabido conducirse con gran tacto y discreción. Me alegro, claro está! Y sentiría que le quitaran de aquel puesto y tuviera que volverse acá a luchar de nuevo. Hayan sido cuales fuesen sus faltas merece unos últimos años de sosiego. Por mi parte quiero olvidar cuanto nos distanció.

\subsection{Os "amigos de Madrid"}

Nesta indagación retrospectiva, resta por saber a razón última da solidariedade extraordinaria do doutor Goyanes Capdevila e os seus "amigos de Madrid" con Unamuno, coa Ditadura en plena ebulición. Dalgún xeito arriscaban a súa propia seguridade.

Eran "facultativos" eses amigos de Madrid que cita Goyanes na súa carta a Unamuno, ou tiñan outro carácter? Mentres Unamuno estaba en Fuerteventura, sabemos que un "coro de médicos" axudou economicamente a súa familia en Salamanca, segundo xa quedou relatado nestas páxinas.

Na carta a Unamuno de 1930, o doutor Goyanes Capdevila só alude a Ossorio y Gallardo como a única persoa informada da dubidosa conduta de Ramón Castañeyra Schamann, tralo confinamento daquel en Fuerteventura. Polo tanto, podemos pensar que o exministro maurista tivo moito que ver con esa relación. Consultadas as cartas de Ossorio y Gallardo a don
Miguel de Unamuno nese período, arquivadas na Casa Museo deste último en Salamanca, comprobamos que non fan mención ningunha a tales feitos.

Con todo, Ossorio y Gallardo era o avogado de Unamuno, mantiña una relación fluída con este, e fora encarcerado pola Ditadura de Primo de Rivera, logo da fuxida de Unamuno desde Fuerteventura a Francia.

\subsection{Ossorio y Gallardo}

O xurista Ossorio y Gallardo, quen sería expulsado do seu colexio profesional polo franquismo como presunto masón, defendera a Unamuno durante o seu soado proceso de 1918 en Valencia. O catedrático de Salamanca fora xulgado entón polas súas aceiradas críticas contra o rei Alfonso XIII e a raíña nai María Cristina.

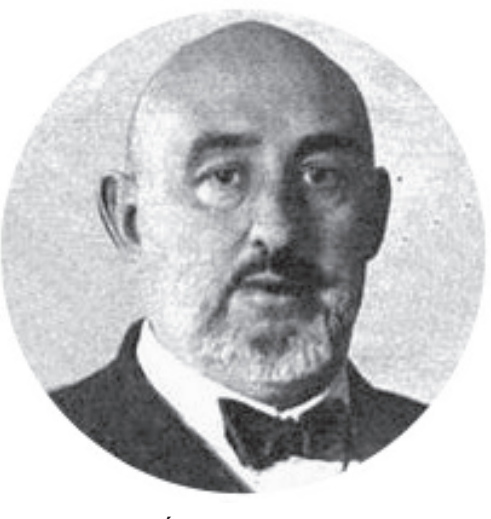

O avogado Ángel Ossorio y Gallardo

Daquela, a masonería entrou en acción para defendelo, se facemos caso ao ensaio Unamuno, los derechos del hombre y la libertad de expresión. Un modelo de campaña masóni$\mathrm{ca}$, obra do investigador José Antonio Ferrer Benimeli, publicada en 1989, curiosamente no Anuario do Arquivo Histórico Insular de Fuerteventura.

Ferrer Benimeli narra nese traballo que o doutor Luis Simarro, gran mestre da Masonería española, se dirixira ás loxas da súa xurisdición o 14 de setembro de 1920 para que promovesen a difusión dunha carta da "Liga Española para la defensa de los derechos del hombre y del ciudadano" que el mesmo presidía. O gran mestre sinalaba na súa circular:

Espera el Gran Consejo que esa respetable logia, como siempre, atenderá esta solicitud, tanto más cuanto que se trata de una causa tan simpática como la defensa de un atropellado por la razón de exponer leal y noblemente en la prensa su pensamiento. 
Corenta e oito horas despois desta circular do doutor Luis Simarro, Unamuno foi condenado a dezaseis anos de cadea e mil pesetas de multa polo tribunal valenciano. Unamuno ordenou recorrer o fallo ao seu letrado Ossorio y Gallardo ante o Tribunal Supremo, que finalmente sobreseu a causa, pola amnistía que despenalizara o seu delito un ano antes.

Polo tanto, as 103 loxas masónicas existentes en España en 1920, segundo o cadro publicado en Berna polo "Bureau Internacional de Relations Maçonniques", tiñan claro o respecto que lle merecía Unamuno ao seu Grande Consello, catro anos antes do seu desterro a Fuerteventura.

\subsection{Cita en Atocha}

Cando xa criamos esgotadas todas as posibilidades de esclarecer as claves deste asunto, demos cun artigo do Dr. Goyanes, publicado en abril de 1954, que ilustra a cuestión. Nesas liñas, inéditas ata agora nas investigacións sobre Unamuno, o cirurxián lucense pon colofón a unha serie de artigos que escribira sobre don Miguel na revista Gaceta Médica Española.

Despois de explicar que Unamuno se opoñía ao golpe de forza levado a cabo por Primo de Rivera, o doutor Goyanes razoaba así:

Si eligió él mismo, Primo de Rivera, el lugar de la residenciación o destierro de Unamuno, puede decirse que en él obró una sarcástica y jocosa ocurrencia andaluza, pues fué decretado su ostracismo en el Puerto de Cabras, capital de la isla de Fuerteventura (fuerte ventura). El día que salió don Miguel para su destierro recibí una llamada telefónica: era el que hablaba el propio don Miguel, para notificármelo y rogarme que acudiera a mediodía a la estación de Atocha. Le habían boicoteado el teléfono de su residencia, pero desde otro le fue posible llamar a dos o tres amigos; $y$, en efecto, en la estación sólo nos hallábamos el doctor Madinaveitia, el señor Ossorio y Gallardo y el que esto suscribe, además de unos pocos estudiantes de medicina.

Y don Miguel me dijo: «Usted tiene en Fuerteventura un amigo que le estima; escríbale para que me atiendan allí». Así lo hice de seguida, $\mathrm{y}$, al efecto, nos reunimos unos cuantos amigos acordando ayudar a financiar sus gastos. Así se hizo; pero las minutas llegaron a ser tan cuantiosas, que todos mis amigos se opusieron a continuar dando sus estipendios, por lo cual se suspendió el envío de nuevas cantidades, con la consecuencia de recibirse del "caro amigo" de Fuerteventura un exhorto en uno de los Juzgados de Madrid, demandando el pago de unos miles de pesetas, basada la demanda en la carta mía; y consultado el caso con Osorio (sic), éste aconsejó pagar, pues las órdenes de arriba serían inapelables ...y así se hizo. (1954: 85-86).

Neste artigo de Goyanes, o doutor refírese a unha carta súa a Castañeyra, cuxo contido descoñecemos. Con todo, aparece en escena un terceiro personaxe de grande interese, o Dr. Juan Madinaveitia Ortiz de Zárate, vasco nado en Oñate, quen tamén concorreu á cita na estación de Atocha, segundo o testemuño do cirurxián de Monforte.

Indagando sobre este galeno vasco, descubrimos un telegrama que Madinaveitia lle enviou a Unamuno naquel transo, cuxo contido foinos facilitado pola Casa Museo de Unamuno en Salamanca (CMU, 34/60). O seu texto reza así: "La incalificable situación actual tenía que llegar necesariamente a esto. Le saluda cariñosamente Juan Madinaveitia". O cable está datado o 2... (ilexible o segundo díxito) de febreiro de 1924. Igualmente hai unha palabra no texto que podería ser "llevar" en lugar de "llegar". Podemos presumir que o telegrama foi remitido por Madinaveitia a Unamuno nas horas previas a que don Miguel abandonase Salamanca camiño do seu confinamento. Coñecido o texto do cablegrama, Unamuno debeu citar, con suma probabilidade, ao doutor Madinaveitia en Atocha, como fixo co doutor Goyanes.

\subsection{Unha hospitalidade fraternal?}

Juan Madinaveitia Ortiz de Zárate era un "santo laico" - ao dicir do Dr. Marañón. Pois ben, este gastroenterólogo vasco foi veciño, parede con parede, doutro colega, o doutor Luis Simarro, Gran Mestre do Grande Oriente Español, citado anteriormente. Tanta era a súa amizade que Simarro o nomeou como un dos seus albaceas testamentarios, antes de falecer en 1921.

Na súa biografía Vida y obra del Doctor Madinaveitia (1985), o doutor Daniel Zulaika Aristi informa de que este médico vasco e Simarro construíran un laboratorio de experimentación, xunto á residencia deste último, na madrileña rúa de General Oráa, número 3. Posteriormente, Juan Madinaveitia edificou a súa propia casa sobre o citado laboratorio. Sorprendentemente, nesta mesma rúa fixaría anos despois a súa morada o cirurxián Goyanes Capdevila.

O libro do doutor Zulaika non vincula directamente a Madinaveitia coa masonería. Nunha entrevista coa súa neta, Carmen Castro Madinaveitia, esta filla de Américo Castro e 


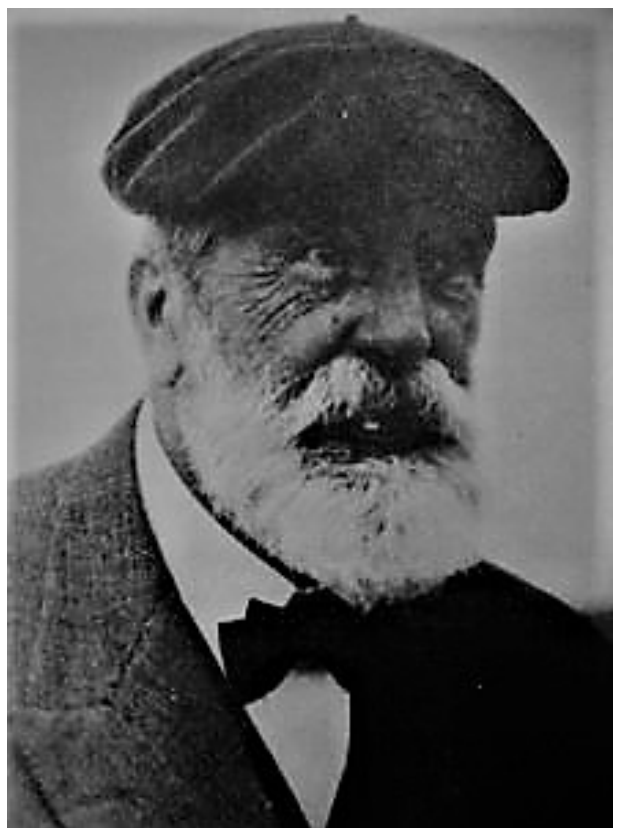

O doutor Juan Madinaveitia Ortiz de Zárate

esposa do filósofo Xabier Zubiri negoulle ao Dr. Zulaika que o seu avó fora masón. Segundo o seu testemuño, o doutor Madinaveitia referíase aos masóns como "los del mandilón" cando visitaban a casa do doutor Simarro.

Fronte á tese sostida por Carmen Castro, un epitafio dedicado á memoria de Madinaveitia convida a pensar o contrario. Escrito polo doutor Juan Negrín López, presidente do Goberno da Segunda República cando foi publicado no xornal La Vanguardia no ano 1938, aparece reproducido no libro do doutor Zulaika. O texto de Negrín reverbera con claros ecos masónicos:

Don Juan Madinaveitia. In Memoriam. Se ha perdido a un Hombre: una especie rara. A un gran Maestro: ¿cuántos Maestros hay entre miríadas de Hombres? A un gran Español. Al Hombre, al Maestro y al gran Español debo y quiero rendir homenaje. Fue también un Gran Técnico. Como tal formó generaciones de médicos. Bastantes aprendieron a ser profesionales. El porvenir dirá si alguno aprendió a ser Hombre. Don Juan Madinaveitia: tus lecciones de médico las rebasará el Progreso, tu Nombre se esfumará con el Tiempo, pero tu espiritu perdurará, porque es un eslabón en el proceso eterno de la Superación humana. Gran Maestro, mi humilde recuerdo. Juan Negrín.

A vinculación de Ossorio y Gallardo e Madinaveitia coa masonería - non acreditada totalmente no caso deste último, segundo queda dito- únese ao feito de que Ramón Castañeyra Schamann era o "herdeiro intelectual e universal" doutro masón acreditado, como o foi Ramón F. Castañeyra.

Tendo en conta a clara simpatía da masonería coa defensa das liberdades e os dereitos humanos, evidenciada no caso de Unamuno en 1920, podemos sospeitar que a citada sociedade discreta tamén estivo detrás da excelente acollida tributada a Unamuno en Fuerteventura, catro anos máis tarde.

Chama a atención neste sentido que Ossorio y Gallardo, letrado de Unamuno, coñecedor das supostas contraprestacións económicas derivadas da hospitalidade tributada ao seu cliente en Fuerteventura, decidira que fosen aboadas, sen que esta operación onerosa saíse á luz por aquel tempo.

\section{Conclusións}

Con motivo do seu confinamento en Fuerteventura en 1924, don Miguel de Unamuno insistiu repetidas veces en que debería ser o Estado quen se fixese cargo dos gastos do seu desterro. Non debe esquecerse que a Ditadura lle suprimira o seu soldo de catedrático en Salamanca.

O grande intelectual rexeitou a axuda económica que lle ofreceu nese transo $\mathrm{M}$. Herriot, en nome do Goberno francés, pero tamén a colaboración pecuniaria do magnate vasco Horacio Echevarrieta. Con todo, un grupo de médicos descoñecido axudou a sustentar a familia do catedrático salmantino nese angustioso período.

Segundo a presente pescuda don Miguel solicitou, pola contra, o apoio do médico galego José Goyanes Capdevila para que o atendesen da mellor manera posible en Fuerteventura, coñecedor da vinculación do galeno coa familia dunha paciente residente na illa. Tal petición fíxose, con toda probabilidade, na madrileña estación de Atocha, en presenza do seu letrado Ossorio y Gallardo, vinculado á masonería, e doutro médico, Juan Madinaveitia, albacea testamentario do Gran Mestre do Grande Oriente Español. O Dr. Goyanes Capdevila escribiulle entón unha carta á familia Castañeyra, de orixe galega pero residente en Fuerteventura, pedindo axuda para Unamuno, tras intervir felizmente a unha adolescente chamada Victoria membro de devandita familia. Seguindo as indicacións do pai desta última, José Castañeyra Carballo, o comerciante Ramón Castañeyra Schamann, irmán da citada paciente, acudiu a recibir a Unamuno en Gran Canaria, viaxando con el ata 
Fuerteventura. Alí oficiou como o seu anfitrión desinteresado durante a súa estadía na illa.

Un grupo de amigos de Madrid, dos que formaban parte con toda probabilidade membros da masonería, encargouse de colaborar con Unamuno, financiando a hospitalidade brindada ao pensador. Malia a adiñeirada posición da familia anfitrioa apelidada Castañeyra, un dos seus membros promoveu un exhorto xudicial, para que o doutor Goyanes Capdevila pagase 3.000 ptas. adicionais polos gastos da súa estadía en Fuerteventura, que os outros amigos de Unamuno rexeitaron aboar.

Ao pisar terra española, Unamuno recibiu unha carta do doutor Goyanes revelándolle a "indigna comedia" do Sr. Castañeyra. Don Miguel non respondeu a esta misiva, nin deixou traslucir en escrito ningún malestar coa familia Castañeyra. Pero xamais volvería á illa canaria, incumprindo a súa firme promesa de facelo, que figura na carta prólogo do seu libro $D e$ Fuerteventura a Paris ${ }^{16}$.
Ata agora era crenza estendida que o confinamento de don Miguel de Unamuno en Fuerteventura fora financiado con fondos do erario, conforme ao seu criterio. Pero o doutor Goyanes Capdevila revelou discretamente, nun artigo dunha publicación médica de 1954, que don Miguel lle pedira axuda -sen especificar o seu carácter- cando pasou por Madrid camiño do seu confinamento.

Supoñemos que o carácter oneroso desta acollida quedou en evidencia cando o chamado Sr. Castañeyra promoveu un exhorto xudicial contra o doutor Goyanes Capdevila, para esixirlle uns miles de pesetas, como compensación polos servizos prestados ao pensador, en Puerto Cabras. A acción xudicial non seguiu adiante, porque Ossorio y Gallardo, letrado de Unamuno e membro da masonería, decidiu que era mellor pagar. En todo caso, esta investigación acredita que Unamuno "nunca camiñou só" durante o seu confinamento, grazas á significativa solidariedade dos seus amigos oriúndos de Galicia.

Trevonzos, 2020

\section{Referencias bibliográficas}

Castañeyra, Ramón F. (1991): Memoria sobre las costumbres de Fuerteventura, escrita para el señor don Juan Bethencourt Alfonso. Puerto del Rosario: Servicio de Publicaciones del Excmo. Cabildo Insular de Fuerteventura.

Castañeyra Schamann, Ramón (2003): Cantares (prólogo de Encarna Castañeyra de la Fe). Fuerteventura: Cabildo Insular de Fuerteventura.

Cerdeña Armas, Francisco J. (2011): “El legado bibliográfico de Ramón Castañeyra Schamann, 1973”, Cuaderno de Puerto Cabras. Notas y apuntes de Historia Local 10/10/2011, https://mis-blogger.blogspot.com/2011/10/el-legado-bibliografico-de-ramon.html [consulta: 15/02/2019].

De Paz Sánchez, Manuel A. (1984): Historia de la francmasonería en Canarias (1739-1936). [Las Palmas de Gran Canaria]: Ediciones del Excmo. Cabildo Insular de Gran Canaria.

Del Arco López, Valentín (1986): “Unamuno frente a Primo de Rivera. De Salamanca al exilio, 1923-1924”, Studia historica. Historia contemporánea 4, pp. 129-179, https://revistas.usal.es/index.php/0213-2087/ article/view/6509.

16 Ignoramos se don Miguel de Unamuno agradeceu ao Dr. Goyanes Capdevila a súa axuda no momento decisivo do seu desterro. Dous anos despois, cando vive expatriado en Francia, recibiu unha carta do profesor de Dereito Penal Luis Jiménez de Asúa, fechada en Perlora (Gijón) o 24 de agosto de 1926, misiva que suscita dúbidas sobre a valoración que o cirurxián lle merecía por aquelas datas. Para contextualizar o contido da carta, anotemos que Jiménez de Asúa saíra había pouco do cárcere, onde estivera preso durante algunhas semanas por resistirse a entregar o Ateneo á Ditadura, logo de permanecer desterrado por esta última en Chafarinas, acusado de liderar a protesta durante o traslado dos restos de Ganivet que, procedentes de Riga, atravesaron Madrid camiño de Granada o 28 de marzo de 1925. Na carta, Jiménez de Asúa quéixase ante o seu "querídisimo maestro" por certas condutas ambiguas fronte á Ditadura primorriverista: "Lo que más me duele son las deserciones. Esos que mueren para nosotros civilmente, como dice Vd. con tan justa frase en su admirable carta. Los Goyanes, que claudican por una subvención al Instituto, los Cajal, que escriben cartas innobles al dictador, inclinados hasta el polvo, aunque les duela doblar la osamenta endurecida por los años" (CMU J/39 bis, 4h). Como outros protagonistas deste traballo, Jiménez de Asúa tamén foi masón, pero ingresaría nesta sociedade un ano despois de escribir esta carta, co nome simbólico de "Carrara", pertencendo ás loxas "Dantón" no 7 e "Primero de mayo". Pola súa banda, o doutor Goyanes, que fora nomeado primeiro director do Instituto Príncipe de Asturias, con fins asistenciais, en 1922, permanecería no cargo ata os anos trinta do século pasado. 
Fernández Larraín, Sergio (ed.) (1972): Cartas inéditas de Miguel de Unamuno. Madrid: Rodas.

Fernández Marrón, Itziar (1998): "Cartas de cuatro juristas republicanos a Miguel de Unamuno 19201936)", Cuadernos de la Cátedra Miguel de Unamuno 33, pp. 193-218, https://dialnet.unirioja.es/ servlet/articulo? codigo $=56789$.

González López, Emilio (1931): El espíritu universitario. Madrid: J. Pueyo.

(1987): Memorias de un estudiante liberal (1903-1931). A Coruña: Ediciós do Castro (Documentos para a historia contemporánea de Galicia, $\left.\mathrm{n}^{\circ} 35\right)$.

Goyanes Capdevila, José (1954): "Con don Miguel de Unamuno y sus amigos y adversarios. Unamuno y la política de su tiempo", Gaceta Médica Española (abril 1954), Sección Paramédica, pp. 84-86.

López Vega, Antonio (ed.) (2008): Epistolario inédito: Marañón, Ortega, Unamuno. Madrid: Fundación Marañón-Ortega y Gasset / Espasa.

Millares, Agustín (1979): "Notas para un estudio sobre la burguesía majorera en el tránsito del XIX al XX". Anuario del Centro Asociado de Las Palmas (UNED) 5 (IV Coloquio de Historia Social), pp. 88-108.

Navarro Artiles, Francisco (1980): Unamuno: artículos y discursos sobre Canarias. Puerto del Rosario: Cabildo Insular de Fuerteventura.

Pérez, Rafael (2017): "Entrevista a don Elías Rodríguez Rodríguez en Puerto del Rosario de Tamariche", El rincón de Tamariche 01/11/2017, https://elrincondetamariche.majorero.es/entrevista-a-don-eliasrodriguez-rodriguez-en-puerto-del-rosario-de-tamariche/ [consulta: 15/02/2019].

Rabaté, Colette e Jean-Claude Rabaté (eds.) (2013): Cartas del destierro. Entre el odio y el amor (19241930). Salamanca: Ediciones Universidad de Salamanca.

Rodríguez Guerra, Alexandre (ed.) (2000): Epistolario galego de Miguel Unamuno. Santiago de Compostela: Xunta de Galicia, Consellería de Educación e Ordenación Universitaria / Centro Ramón Piñeiro para a Investigación en Humanidades.

Rodríguez Rodríguez, Elías (2013): "Buenaventura Durruti en Puerto de Cabras (Fuerteventura, 1932)", Fuerteventura limpia, http://fuerteventuralimpia.blogspot.com/search?q=durruti [consulta: 15/02/2019].

Salcedo, Emilio (1998 [1964]): Vida de don Miguel (Unamuno, un hombre en lucha con su leyenda). Salamanca: Anthema Edicións.

Soriano, Rodrigo (1931): España bajo el sable. Treinta años de combates (Prólogo: "La resurrección de España" de Julio R. Barcos). Buenos Aires: Claridad.

Zulaika, Daniel (1985): Vida y obra del Dr. Madinaveitia. Zarautz: Diputación Foral de Guipúzcoa. 